\title{
Pemodelan Keparahan Penyakit Blas pada Tanaman Padi di Kabupaten Subang
}

\section{Modelling on Rice Blast Disease Severity in Subang District}

\author{
Zulaika*, Bonny Poernomo Soekarno, Ali Nurmansyah \\ Institut Pertanian Bogor, Bogor 16680
}

\begin{abstract}
ABSTRAK
Penyakit blas (Pyricularia oryzae) merupakan penyakit utama pada tanaman padi di Indonesia. Penyusunan model peramalan keparahan penyakit blas berdasarkan faktor budi daya, letak geografi, dan unsur cuaca merupakan alternatif pengendalian secara preventif yang belum banyak dilakukan. Oleh karena itu, penelitian ini dilakukan dengan tujuan mendapatkan model peramalan keparahan penyakit blas berdasarkan faktor-faktor tersebut. Penelitian dilakukan dengan melakukan pengamatan keparahan penyakit, pengumpulan informasi terkait teknik budi daya dan pengamatan kondisi cuaca di stasiun pengamatan Balai Besar Tanaman Padi Subang, Jawa Barat. Hasil persamaan pemodelan keparahan penyakit blas, yaitu $\mathrm{Y}=-67.17+5.51 \mathrm{X}_{1}-10.54 \mathrm{X}_{2}+13.26 \mathrm{X}_{3}+8.51 \mathrm{X}_{4}+2.29 \mathrm{X}_{5}+1.32 \mathrm{X}_{6}$ $+8.47 \mathrm{X}_{7}+0.31 \mathrm{X}_{8}+4.53 \mathrm{X}_{9}$ (nilai $\mathrm{p}<0.0001, \mathrm{R}^{2}=0.85$ ). Intensitas penggunaan pupuk $\mathrm{N}$ dan umur tanaman memiliki hubungan yang nyata terhadap peningkatan keparahan penyakit blas. Peningkatan 1 kali intensitas pupuk $\mathrm{N}$ dapat meningkatkan keparahan penyakit blas sebesar $8.47 \%$. Peningkatan umur tanaman setiap harinya meningkatkan keparahan penyakit sebesar $0.31 \%$. Infeksi patogen pada benih setelah panen memiliki korelasi yang kuat dan positif dengan infeksi sebelum tanam dengan nilai korelasi 0.78 , artinya keparahan penyakit benih setelah panen dipengaruhi oleh $78 \%$ infeksi patogen benih sebelum tanam. Hasil analisis regresi linier sederhana $Y=5.98+2.41 \mathrm{X}$ (nilai $\mathrm{p}=0.01, \mathrm{R} 2=0.61$ ) yang menunjukkan bahwa kenaikan $1 \%$ patogen terbawa benih sebelum tanam akan meningkatkan persentase keparahan penyakit sebesar $2.41 \%$ setelah benih dipanen. Hasil penelitian ini dapat dijadikan acuan dalam menyusun teknik pengendalian secara preventif dan mengurangi risiko patogen terbawa benih yang berperan sebagai sumber inokulum awal.
\end{abstract}

Kata kunci: cuaca, pengendalian preventif, prediksi, Pyricularia oryzae, regresi

\section{ABSTRACT}

Blast disease (Pyricularia oryzae) is a major diseases of rice in Indonesia. Research related to modelling of blast disease severity is limited. Therefore, this study aimed to design a statistical model on rice blast disease infestation on the rice paddy and to asses a correlation between the disease severity and infected seed level. The models were constructed based on multiple linier regression analyses. The study was conducted by observing the disease severity, collecting information about cultivation technique and weather conditions. The result of regression analysis showed severity modeling on influencing factors is $\mathrm{Y}=-67.17+5.51 \mathrm{X} 1-10.54 \mathrm{X}_{2}+13.26 \mathrm{X}_{3}+8.51 \mathrm{X}_{4}+2.29 \mathrm{X}_{5}+1.32 \mathrm{X}_{6}+8.47 \mathrm{X}_{7}+0.31 \mathrm{X}_{8}+4.53 \mathrm{X}_{9}$ ( $\mathrm{p}$-value $<0.0001, \mathrm{R}^{2}=0.85$ ). Nitrogen application and plant ages had significant effect on disease severity. The addition of $\mathrm{N}$ fertilizer increased the severity of blast disease by $8.47 \%$. Increasing the daily life of plants increases the disease severity by $0.31 \%$. The correlation (r) of pathogen infection after harvesting was strongly influenced by infection before planting with correlation value of 0.78 . This

*Alamat penulis korespondensi: Departemen Proteksi Tanaman, Fakultas Pertanian, Institut Pertanian Bogor. Jalan Kamper, Kampus IPB Darmaga, Bogor 16680

Tel: 0251-8621267, Faks: 0251-8621267, Surel: zulaikha.azkya@gmail.com 
means that the severity of seed disease after harvesting is influenced by $78 \%$ infection of pathogenic seed before planting. The result of regression analysis showed $\mathrm{Y}=5.98+2.41 \mathrm{X}$ ( $\mathrm{p}$-value $=0.0076, \mathrm{R}^{2}$ $=0.61$ ). An increase of $1 \%$ pathogens carried by seed before planting will be increasing disease severity by $2.41 \%$ after harvesting. The results of this study can be used as a reference in preparing preventive control measure and reduce the risk of pathogen carried by seeds that act as a source of initial inoculum.

Key words: prediction, preventive control, Pyricularia oryzae, regression, weather

\section{PENDAHULUAN}

Padi (Oryza sativa) merupakan salah satu komoditas pangan yang terus diproduksi di seluruh dunia. FAO (2016) melaporkan bahwa produksi padi di 4 negara pengonsumsi beras terbesar di Asia pada tahun 2015 mencapai 200 juta ton di Cina, 170 juta ton di India, 50 juta ton di Indonesia, dan 20 juta ton di Bangladesh. Data di atas menunjukkan padi merupakan komoditas penting yang intensif dibudidayakan di negara-negara tersebut. Intensifikasi penanaman padi menyebabkan beberapa masalah seperti timbulnya penyakit tanaman. Salah satu penyakit penting pada padi ialah penyakit blas yang disebabkan oleh cendawan Pyricularia oryzae. Infestasi penyakit ini sangat memengaruhi kualitas dan kuantitas produksi padi. Wang et al. (2014) melaporkan bahwa kehilangan hasil produksi padi akibat gangguan penyakit ini bervariasi di berbagai negara seperti Jepang, Brazil, India, Korea, China, Filipina, Vietnam, Italia, Iran, dan Indonesia berturut-turut sebesar $20-100 \%, 100 \%, 5-10 \%, 8 \%, 14 \%, 50-85 \%$, $38-83 \%$, 22-26\%, 20-80\%, dan 50-90\%.

Sebelumnya, penyakit blas di Indonesia diketahui hanya menyerang padi gogo tetapi saat ini sudah ditemukan menginfeksi pertanaman padi sawah. Penyakit blas dilaporkan banyak ditemukan pada padi sawah irigasi, terutama di Jawa Barat (Subang, Karawang, dan Indramayu), Jawa Tengah (Pemalang, Pekalongan, Batang, Demak, Jepara, dan Blora), dan Jawa Timur (Lamongan, Jombang, Mojokerto, Pasuruan, Probolinggo, dan Lumajang) (Amir 2003).

Penelitian terkait pengendalian penyakit blas selama ini meliputi topik-topik deteksi patogen terbawa benih (Arifin et al. 2014), perakitan varietas tahan (Ribot et al. 2008), epidemiologi penyakit blas (Geer dan Webster 2001), dan resistensi penyakit blas terhadap bahan kimia (Swamy et al. 2009). Keparahan penyakit blas dapat diprediksi berdasarkan faktor-faktor yang memengaruhinya. Oleh karena itu, penelitian ini dilakukan untuk menyusun model keparahan penyakit blas berdasarkan pada faktor budi daya, letak geografi, variabel cuaca, serta korelasi antara infeksi patogen terbawa benih sebelum tanam dan setelah panen.

\section{BAHAN DAN METODE}

Penelitian dilaksanakan pada November 2016 hingga April 2017 (musim hujan). Pengamatan infeksi penyakit blas dilakukan di Kecamatan Cisalak dan Sukamandi Kabupaten Subang yang merupakan salah satu sentra produksi padi di Jawa Barat. Subang ini memiliki 2 kondisi geografi, yaitu dataran tinggi dan dataran rendah sehingga cara budi dayanya berbeda.

Kerentanan varietas, aplikasi jerami, sistem penanaman (legowo 10 dan umum), pengendalian gulma, intensitas penggunaan herbisida, intensitas penggunaan fungisida, intensitas aplikasi pupuk $\mathrm{N}$ didapatkan dari kuesioner hasil wawancara dengan petani. Insidensi penyakit dan umur tanaman diamati langsung di lapangan. Data ketinggian tempat, suhu, kelembapan, dan curah hujan didapatkan dari Balai Besar Penelitian Tanaman Padi dari bulan November 2016 hingga Februari 2017. Data yang diperoleh dianalisis menggunakan metode analisis regresi.

\section{Pengamatan Keparahan Penyakit Blas di Lapangan}

Pengamatan keparahan penyakit blas dilakukan pada 10 lahan sawah (5 lahan di 
Sukamandi dan 5 lahan di Cisalak) dengan jumlah tanaman yang diamati $10 \%$ dari jumlah totaltanaman. Keparahan penyakitdiamatipada fase vegetatif awal (30 HST), vegetatif akhir (60 HST), dan generatif (90 HST). Penentuan tingkat keparahan penyakit menggunakan skoring dengan nilai skala berdasarkan Standar Evaluation System for Rice (IRRI 1996) dan dihitung dengan rumus sebagai berikut:

$$
\mathrm{KP}=\frac{\sum_{i=0}^{i}\left(\mathrm{n}_{i} \times \mathrm{v}_{i}\right)}{\mathrm{N} \times \mathrm{V}} \times 100 \% \text {, dengan }
$$

$\mathrm{KP}$, keparahan penyakit; $\mathrm{v}_{i}$, nilai skala dari tiap kategori serangan; $\mathrm{n}_{i}$, jumlah rumpun yang terserang; N, jumlah tanaman yang diamati; $\mathrm{Z}$, nilai skala tertinggi.

Penyusunan Model Keparahan Penyakit Blas

Uji asumsi meliputi uji kenormalan dan uji heteroskedastisitas. Uji kenormalan digunakan untuk melihat data menyebar secara normal atau tidak menggunakan metode KolmogrovSmirnov. Uji heteroskedastisitas dalam analisis regresi dilakukan untuk melihat kehomogenan data menggunakan uji White.

Kriteria model terbaik ditentukan berdasarkan pada nilai-p dari uji terhadap model (uji F) tertinggi, nilai R2 tertinggi, dan nilai kuadrat tengah galat (KTG) terendah. Variabel pengamatan dalam penyusunan model terdiri atas faktor budi daya, letak geografi, dan unsur cuaca. Penyusunan model menggunakan analisis regresi linier berganda dengan asumsi hubungan antara variabel bebas dan variabel terikat bersifat linier. Kombinasi model terdiri atas faktor budi daya dengan salah satu dari letak geografi atau variabel cuaca (Tabel 1). Persamaan model regresi linier berganda yang digunakan dalam penyusunan model, yaitu:

$$
\mathrm{Y} i=\beta \mathrm{o}+\beta 1 \mathrm{X} 1 i+\beta 2 \mathrm{X} 2 i+\ldots+\beta \mathrm{pXp} i+\varepsilon i,
$$

dengan $\mathrm{Y} i$, variabel terikat pada pengamatan ke-i untuk $\mathrm{i}=1,2, \ldots, \mathrm{n} ; \beta 0-\beta p$, peubah model; $\mathrm{X} 1 i-\mathrm{Xp} i$, variabel bebas; $\varepsilon \mathrm{i}$, sisa (error) pada pengamatan ke-i. Pendugaan parameter dilakukan menggunakan metode kuadrat terkecil dengan syarat uji asumsi telah terpenuhi.

\section{Hubungan Benih Terinfeksi Sebelum Tanam dan Setelah Panen}

Sampel benih merupakan sisa tanam dan hasil panen yang berasal dari 10 lahan yang berbeda-beda. Sebanyak 25 butir benih diuji dan diulang 4 kali untuk masing- masing lahan pengamatan. Benih disterilkan permukaannya dan diletakkan di atas medium agar-agar dekstrosa kentang (ADK) 50\%. Ruang inkubasi disinari menggunakan near-ultraviolet selama 7 hari pada suhu ruang, kemudian dihitung presentase benih yang menunjukkan adanya koloni cendawan P. oryzae. Hasil pengamatan cendawan $P$. oryzae terbawa benih kemudian

\begin{tabular}{|c|c|c|c|c|c|c|}
\hline \multirow{2}{*}{\multicolumn{2}{|c|}{ Variabel X }} & \multirow{2}{*}{ Keterangan } & \multicolumn{4}{|c|}{ Calon model } \\
\hline & & & 1 & 2 & 3 & 4 \\
\hline $\mathrm{X}_{1}$ & Kerentanan varietas & Tahan, Moderat, Rentan & $\sqrt{ }$ & $\sqrt{ }$ & $\sqrt{1}$ & $\sqrt{ }$ \\
\hline$X_{2}$ & Aplikasi jerami & Tidak (0), Ya (1) & $\sqrt{ }$ & $\sqrt{ }$ & $\sqrt{ }$ & $\sqrt{ }$ \\
\hline $\mathrm{X}_{3}$ & Sistem penanaman & Umum, Legowo 10 & $\sqrt{ }$ & $\sqrt{ }$ & $\sqrt{ }$ & $\sqrt{ }$ \\
\hline$X_{4}$ & Pengendalian gulma & Herbisida, Manual dan herbisida & $\sqrt{ }$ & $\sqrt{ }$ & $\sqrt{ }$ & $\sqrt{ }$ \\
\hline$X_{5}$ & Intensitas penggunaan herbisida & 1 kali dan 3 kali & $\sqrt{ }$ & $\sqrt{ }$ & $\sqrt{ }$ & $\sqrt{ }$ \\
\hline$X_{6}$ & Intensitas penggunaan fungisida & 3 kali dan 5 kali & $\sqrt{ }$ & $\sqrt{ }$ & $\sqrt{ }$ & $\sqrt{ }$ \\
\hline $\mathrm{X}_{7}$ & Intensitas aplikasi pupuk $\mathrm{N}$ & 1 kali dan 3 kali & $\sqrt{ }$ & $\sqrt{ }$ & $\sqrt{ }$ & $\sqrt{ }$ \\
\hline$X_{8}$ & Umur tanaman & $30,60,90$ hari setelah tanam & $\sqrt{ }$ & $\sqrt{ }$ & $\sqrt{ }$ & $\sqrt{ }$ \\
\hline$X_{9}$ & Ketinggian tempat & $<250$ dan 500-750 mdpl & $\sqrt{ }$ & & & \\
\hline & Suhu & ${ }^{\circ} \mathrm{C}$ & & $\sqrt{ }$ & & \\
\hline & Kelembapan & $\%$ & & & $\sqrt{ }$ & \\
\hline $\mathrm{X}_{12}$ & Curah hujan & $\mathrm{mm} \mathrm{hari}^{-1}$ & & & & $\sqrt{ }$ \\
\hline
\end{tabular}

Tabel 1 Kombinasi variabel $\mathrm{X}$ dalam penyusunan calon model keparahan penyakit blas 
dianalisis menggunakan analisis regresi linier sederhana dengan persamaan:

$$
\mathrm{Y}=\mathrm{ax}+\mathrm{b} \text {. }
$$

$\mathrm{Y}$ merupakan persentase infeksi benih setelah panen dan $\mathrm{x}$ merupakan persentase infeksi sebelum tanam. Analisis korelasi (r) dilakukan untuk mengetahui keeratan hubungan antara infeksi penyakit benih sebelum tanam dan setelah panen.

\section{HASIL}

\section{Model Keparahan Penyakit Blas}

Hasil uji kenormalan secara kuantitatif berdasarkan uji Kolmogrov-Smirnov menunjukkan nilai-p dari keempat model lebih besar dari $\alpha=0.05$ yang berarti data menyebar normal. Model 1 nilai-p $=0.19$ dan model 2, 3 , serta 4 memiliki nilai-p $=0.20$ sehingga dapat disimpulkan keempat model tersebut memenuhi syarat kenormalan data.

Hasil uji heteroskedastisitas dari keempat model kuantitatif melalui uji White menunjukkan nilai-p lebih besar dari $\alpha=$ 0.05 maka data bersifat homogen. Model 1 memiliki nilai-p $=0.5214$ dan model 2, 3, 4 memiliki nilai-p $=0.8865$ sehingga dapat disimpulkan keempat model memenuhi syarat uji asumsi bahwa data bersifat homogen.

\section{Model Terbaik}

Calon model terbaik yang dipilih ialah model 1. Hal ini berdasarkan analisis uji $\mathrm{F}$ yang nyata dengan nilai-p kurang dari $\alpha=0.01$, nilai R2 yang mencapai $85 \%$, dan nilai kuadrat tengah galat (KTG) terendah (Tabel 2). Persamaan model 1 ialah $\mathrm{Y}=-67.17+5.51 \mathrm{X}_{1}$ $-10.54 \mathrm{X}_{2}+13.26 \mathrm{X}_{3}+8.51 \mathrm{X}_{4}+2.29 \mathrm{X}_{5}+$ $1.32 \mathrm{X}_{6}+8.47 \mathrm{X}_{7}+0.31 \mathrm{X}_{8}+4.53 \mathrm{X}_{9}$ (nilai- $\mathrm{p}=$ $\left.<0.0001, \mathrm{R}^{2}: 0.85\right)$.
Hasil persamaan menunjukkan bahwa faktor kerentanan varietas, aplikasi jerami, sistem penanaman, pengendalian gulma penggunaan herbisida dan fungisida, pemupukan $\mathrm{N}$, umur tanaman dan ketinggian tempat secara bersama-sama berpengaruh sangat nyata dan berkontribusi dalam meningkatkan keparahan penyakit blas sebesar $85 \%$. Hasil analisis regresi menunjukkan kombinasi model 1 pada variabel X7 (intensitas pemupukan $\mathrm{N}$ ) memiliki pengaruh nyata dengan nilai-p kurang dari $\alpha=0.05$. Nilai koefisien pada peubah intensitas pemupukan $\mathrm{N}$ menunjukkan bahwa peningkatan sebanyak 1 kali pemberian pupuk $\mathrm{N}$ dapat meningkatkan keparahan penyakit blas sebesar $8.47 \%$, apabila peubah yang lain konstan. Umur tanaman juga memiliki pengaruh nyata terhadap perkembangan penyakit blas dengan nilai-p kurang dari $\alpha=0.01$. Hasil pemodelan memprediksi peningkatan umur tanaman setiap harinya dapat meningkatkan keparahan penyakit sebesar $0.31 \%$ jika peubah lain bersifat konstan.

Hasil analisis juga menunjukkan bahwa secara parsial variabel lainnya $\left(X_{1}, X_{2}\right.$, $\mathrm{X}_{3}, \mathrm{X}_{4}, \mathrm{X}_{5}, \mathrm{X}_{6}$, dan $\mathrm{X}_{9}$ ) memiliki pengaruh terhadap peningkatan keparahan penyakit blas dengan syarat variabel lainnya diasumsikan konstan (Tabel 3). Kerentanan varietas benih berpeluang meningkatkan keparahan penyakit sebesar 5.5\%. Lahan dengan aplikasi jerami berpeluang menurunkan keparahan penyakit sebesar $10.5 \%$. Sistem penanaman jajar legowo 10 memiliki korelasi meningkatkan keparahan penyakit sebesar $13.2 \%$ dibandingkan dengan sistem penanaman secara umum. Mekanisme pengendalian gulma yang dilakukan menggunakan herbisida dengan peningkatan intensitas penyemprotan

Tabel 2 Nilai-p hasil uji terhadap model, $\mathrm{R}^{2}$, dan kuadrat tengah galat (KTG) dari 4 calon model keparahan penyakit blas

\begin{tabular}{lcccc}
\hline Model & Variabel & Nilai-p & $\mathrm{R}^{2}$ & KTG \\
\hline 1 & $\mathrm{X}_{1} \mathrm{X}_{2} \mathrm{X}_{3} \mathrm{X}_{4} \mathrm{X}_{5} \mathrm{X}_{6} \mathrm{X}_{7} \mathrm{X}_{8}$ & $<0.0001$ & 0.8500 & 28.6768 \\
2 & $\mathrm{X}_{1} \mathrm{X}_{2} \mathrm{X}_{3} \mathrm{X}_{4} \mathrm{X}_{5} \mathrm{X}_{6} \mathrm{X}_{7} \mathrm{X}_{10}$ & $<0.0001$ & 0.8548 & 29.1625 \\
3 & $\mathrm{X}_{1} \mathrm{X}_{2} \mathrm{X}_{3} \mathrm{X}_{4} \mathrm{X}_{5} \mathrm{X}_{6} \mathrm{X}_{7} \mathrm{X}_{8}$ & $<0.0001$ & 0.8548 & 29.1625 \\
4 & $\mathrm{X}_{1} \mathrm{X}_{2} \mathrm{X}_{3} \mathrm{X}_{4} \mathrm{X}_{5} \mathrm{X}_{6} \mathrm{X}_{7} \mathrm{X}_{12}$ & $<0.0001$ & 0.8548 & 29.1625 \\
\hline
\end{tabular}


Tabel 3 Koefisien, t-hitung dan nilai-p hasil analisis terhadap model keparahan penyakit blas

\begin{tabular}{llrcc}
\hline \multicolumn{1}{c}{ Variabel X dan konstanta } & Koefisien & t-hitung & Nilai-p \\
\hline & Konstanta & -67.17 & -1.67 & 0.10 \\
$\mathrm{X}_{1}$ & Tingkat kerentanan varietas & 5.51 & 1.45 & 0.15 \\
$\mathrm{X}_{2}$ & Aplikasi jerami & -10.54 & -1.45 & 0.16 \\
$\mathrm{X}_{3}$ & Sistem penanaman & 13.26 & 1.14 & 0.26 \\
$\mathrm{X}_{4}$ & Pengendalian gulma & 8.51 & 0.87 & 0.39 \\
$\mathrm{X}_{5}$ & Intensitas penggunaan herbisida & 2.29 & 1.04 & 0.30 \\
$\mathrm{X}_{6}$ & Intensitas penggunaan fungisida & 1.32 & 0.69 & 0.49 \\
$\mathrm{X}_{7}$ Intensitas pemupukan N & 8.47 & 2.23 & 0.03 \\
$\mathrm{X}_{8}$ & Umur tanaman & 0.31 & 7.78 & 0.00 \\
$\mathrm{X}_{9}$ & Ketinggian & 4.53 & 6.55 & 0.30 \\
\hline
\end{tabular}

berkorelasi meningkatkan keparahan penyakit sebesar 2.3\%. Peningkatan aplikasi fungisida berpeluang meningkatkan keparahan penyakit sebesar $1.32 \%$, sedangkan faktor ketinggian tempat menunjukkan bahwa semakin tinggi suatu lahan berpotensi meningkatkan keparahan penyakit sebesar $4.53 \%$.

\section{Hubungan Tingkat Infeksi Benih Sebelum Tanam dan Setelah Panen}

Peningkatan persentase patogen $P$. oryzae terbawa benih diuji menggunakan uji T dengan nilai-p $=<0.0000001$ kurang dari $\alpha=0.05$ yang menunjukkan adanya perbedaan yang nyata pada persentase infeksi patogen $P$. oryzae sebelum tanam dan setelah di panen. Hasil analisis regresi linier sederhana $\mathrm{Y}=5.98+2.41 \mathrm{X}($ nilai- $\mathrm{p}=0.0076, \mathrm{R} 2: 0.6111)$ menunjukkan bahwa kenaikan $1 \%$ patogen terbawa benih sebelum tanam akan meningkatkan persentase keparahan penyakit sebesar $2.41 \%$ setelah benih dipanen. Nilai-p 0.0076 menunjukkan peubah $\mathrm{X}$ memiliki pengaruh yang nyata terhadap $\mathrm{Y}$, sedangkan nilai $\mathrm{R}^{2} 0.6111$ artinya sebesar $61.11 \%$ terbawa benih saat panen dipengaruhi oleh adanya sumber inokulum benih sebelum ditanam. Korelasi yang kuat terlihat antara patogen yang menginfeksi benih sebelum tanam dan setelah panen dengan nilai korelasi sebesar 0.78 . Artinya besarnya infeksi patogen pada benih setelah panen dipengaruhi kuat adanya infestasi patogen sebelum tanam.

\section{PEMBAHASAN}

Hasil analisis regresi menunjukkan kombinasi model 1 pada variabel $\mathrm{X}_{7}$ (intensitas pemupukan N) memiliki pengaruh nyata dengan nilai-p kurang dari $\alpha=0.05$. Penggunaan pupuk $\mathrm{N}$ yang berlebihan akan menghasilkan jumlah anakan tanaman padi lebih banyak sehingga menjadikan iklim mikro yang kondusif bagi perkembangan penyakit blas (Shafaullah et al. 2011). Kelebihan pupuk $\mathrm{N}$ membuat tanaman menjadi lebih rentan karena dapat melemahkan jaringan tanaman dan lebih mudah untuk dipenetrasi oleh patogen (Seebold et al. 2004).

Faktor umur tanaman juga berpengaruh nyata terhadap peningkatan penyakit blas. Akhsan dan Palupi (2015) melaporkan besarnya keparahan penyakit blas pada varietas Inpari 7, Cibogo, dan Ciherang pada minggu pertama sebesar 5\%, 3\%, dan 3.6\%. Pada minggu ke-12 keparahan penyakit meningkat menjadi $82 \%, 23 \%$ dan $57 \%$ yang disebabkan antara lain: semakin tua umur tanaman maka jumlah anakan dan daun tanaman padi semakin banyak yang menyebabkan kelembapan mikro di sekitar tanaman padi semakin meningkat. Hal ini memberi kondisi optimum pada patogen untuk terus berkembang. Faktor umur tanaman yang panjang memberi kesempatan bagi patogen untuk memperbanyak pengulangan siklus hidupnya sehingga intensitas penyakit semakin meningkat. 
Faktor kerentanan varietas benih berpeluang meningkatkan keparahan penyakit blas sebesar $5.5 \%$. Sistem pengendalian yang tepat ialah dengan menanam varietas tahan dalam jangka waktu dan luas area tertentu. Penanaman varietas tahan blas dapat mengurangi intensitas penyakit dan menekan epidemi penyakit blas di lapangan. Variabel lainnya ialah pengembalian jerami ke lahan pertanaman padi. Pengembalian jerami ini dapat memperlambat kehilangan unsur hara seperti Si dan K di dalam tanah. Komponen unsur hara $\mathrm{Si}$ dan $\mathrm{K}$ juga berfungsi untuk meningkatkan ketegaran jaringan tanaman sehingga dapat mengurangi infeksi patogen. Cho dan Kobata (2002) melaporkan dengan pembenaman jerami ke lahan sawah sebanyak 5 ton ha $^{-1}$ per musim selama 4 musim tanam dapat menggantikan keperluan pupuk $\mathrm{K}$, memperbaiki kesuburan tanah, dan mengurangi adanya infeksi patogen. Faktor sistem penanaman memiliki pengaruh terhadap jarak tanam yang berhubungan dengan masuknya sinar matahari ke dalam sela-sela rumpun tanaman padi. Jarak tanam yang terlalu rapat dapat menghambat sinar matahari masuk sehingga menyebabkan kondisi iklim mikro lembap, suhu yang relatif hangat sehingga optimum bagi patogen untuk berkembang. Penggunaan bahan kimia sintetik pada lahan pertanaman padi dapat menyebabkan pelemahan jaringan tanaman padi sehingga memudahkan patogen $P$. oryzae untuk menginfeksi, menyebabkan efek resistensi terhadap hama, penyakit, maupun gulma, menyebabkan keracunan pada tanaman utama, menghambat pertumbuhan tanaman padi, dan menyebabkan pencemaran air, tanah maupun udara (Swamy et al. 2009). Faktor ketinggian tempat juga menunjukkan pengaruh terhadap tingkat keparahan penyakit blas. Semakin tinggi lokasi suatu lahan pertanaman maka suhu akan semakin rendah.

Faktor budi daya seperti kerentanan varietas, aplikasi jerami, sistem penanaman, pengendalian gulma, intensitas penggunaan herbisida, intensitas penggunaan fungisida, intensitas aplikasi pupuk N, umur tanaman, dan faktor letak geografi seperti ketinggian tempat, secara bersama-sama berkontribusi dalam meningkatkan keparahan penyakit blas. Faktor lain seperti intensitas penggunaan pupuk $\mathrm{N}$ dan umur tanaman secara parsial memiliki pengaruh nyata dan sangat nyata terhadap keparahan penyakit blas jika faktor lainnya konstan. Hasil pemodelan ini dapat dijadikan informasi awal besarnya laju peningkatan keparahan penyakit blas berdasarkan variabel yang digunakan. Hasil penelitian ini dapat dijadikan acuan dalam menyusun teknik pengendalian secara preventif dan mengurangi risiko patogen terbawa benih yang berperan sebagai sumber inokulum awal.

Hasil penelitian ini dapat dijadikan acuan untuk memprediksi besarnya potensi patogen P. oryzae yang terbawa benih dengan adanya sumber inokulum awal dan infeksi pada benih setelah dipanen. Korelasi yang kuat antara patogen yang menginfeksi benih sebelum tanam dan setelah panen menunjukkan peluang terjadinya penyakit blas cukup besar jika sumber inokulum awal tidak dikendalikan. Upaya pengendalian yang dapat dilakukan ialah menanam benih yang bebas patogen, perlakuan benih menggunakan agens hayati dan bahan kimia sintetik.

\section{DAFTAR PUSTAKA}

Akhsan N, Palupi PJ. 2015. Pengaruh waktu terhadap intensitas penyakit blas dan keberadaan spora Pyricularia oryzae (Cooke) Sacc. pada lahan padi sawah (Oryza sativa) di Kecamatan Samarinda Utara. Ziraa'ah Majalah Ilmiah Pertanian. 40(2):114-122.

Amir M. 2003. Pemetaan ras Pyricularia grisea di daerah endemik blas di sentra produksi padi sawah dan padi gogo. Laporan Penelitian Balai Penelitian Tanaman Padi.

Arifin MS, Trisusilowati EB, Mihardjo PA. 2014. Efisiensi penularan penyakit blas melalui benih pada varietas padi unggul nasional di Kabupaten Jember [skripsi]. Jember (ID): Universitas Jember.

Cho YS, Kobata T. 2002. N top-dressing and rice straw application for low input 
cultivation of transplanted rice in Japan. Kor J Crop Sci. 47(4):273-278.

[FAO] Food and Agriculture Organization of the United Nation. 2016. Rice market monitor. 19(1):1-41.

Geer CA, Webster RK. 2001. Occurrence distribution, epidemiology, cultivar reaction and management of rice blast disease in California. Plant Dis. 85(10):1096-1102. DOI: https://doi. org/10.1094/PDIS.2001.85.10.1096.

IRRI. 1996. Standard Evaluation System for Rice. Los Banos (PH): IRRI.

Ribot CJ, Hirsch SBL, Tharreau D Notteghem JH, Lebrun MH,Morel JB. 2008. Susceptibility of rice to the blast fungus Magnapothe grisea. J Plant Physiol. 165(1):114-124. DOI: https://doi. org/10.1016/j.jplph.2007.06.013.

Seebold KW, Datnof JLE, Correa-victoria FJ, Kuchare KTA and Snyder GH. 2004. Effect of silicon, nitrogen, and fungicides on the control of leaf and neck blast in upland rice. Plant Dis. 88(3):253-258. DOI: https:// doi.org/10.1094/PDIS.2004.88.3.253.

Shafaullah M, Khan A, Khan NA, Mehmood Y. 2011. Effect of epidemiological factors on the incidence of paddy blast (Pyricularia oryzae) disease. Pak J Phytopathol. 23(2):108-111.

Swamy HN, Sannaulla S, Kumar MD. 2009. Evaluation of new fungicides and herbicides against rice blast in Cauvery Delta. J Plant Dis. 22(2):450-451.

Wang X, S Lee, J Wang, J Ma, T Bianco, Y Jia. 2014. Current advances on genetic resistance to rice blast disease Di dalam: Yan W, Bao J, editor. RiceGermplasm, Genetics, and Improvement. Intech. 195-217. DOI: http://dx.doi. org/10.5772/56824. 